\title{
Odonate Communities of the Sucupira Reservoir, Rio Uberabinha, Minas Gerais, Brazil
}

\author{
Marcela Silva Barbosa ${ }^{1,4}$; Lucas Rodrigues Borges ${ }^{1,5}$; Diogo Silva Vilela ${ }^{2,6}$; Henrique Venâncio ${ }^{2,7}$ \& Jean Carlos Santos ${ }^{3,8}$ \\ 1 Universidade Federal de Uberlândia (UFU), Instituto de Biologia (INBIO), Laboratório de Ecologia, Evolução e Biodiversidade (LEEBIO). \\ Uberlândia, MG, Brasil. \\ ${ }^{2}$ Universidade de São Paulo (USP), Faculdade de Filosofia, Ciências e Letras de Ribeirão Preto (FFCLRP), \\ Programa de Pós-Graduação em Entomologia. Ribeirão Preto, SP, Brasil. \\ ${ }^{3}$ Universidade Federal de Sergipe (UFS), Departamento de Ecologia (DECO). Aracaju, SE, Brasil. \\ ${ }^{4}$ ORCID: http://orcid.org/0000-0003-1313-6081. E-mail: marcela.2802@outlook.com \\ ${ }^{5}$ ORCID: http://orcid.org/0000-0002-7314-0886. E-mail: ecolucasbio@gmail.com \\ ${ }^{6}$ ORCID: http://orcid.org/0000-0001-6510-7018. E-mail: deeog00@gmail.com \\ 7 ORCID: http://orcid.org/0000-0001-9924-0212.E-mail: henrivens@gmail.com \\ ${ }^{8}$ ORCID: http://orcid.org/0000-0001-6031-9193. E-mail: jcsantosbio@gmail.com
}

\begin{abstract}
Dragonflies and damselflies (Insecta: Odonata) are widely distributed among freshwater ecosystems of tropical and temperate environments. They are also particularly sensitive to anthropogenic changes. The objective of this study was to inventory the odonate fauna of a section of the Sucupira Reservoir on Rio Uberabinha, Uberlândia, Minas Gerais, Brazil, and to document the species composition of the odonate fauna during the dry and rainy seasons. The study also aimed to describe the distribution of the sampled species in Brazilian states. Sampling took place in August and September of 2017 (dry season) and in February and March of 2018 (rainy season), and recorded 860 individuals of 43 species belonging to 26 genera and six families. Six new records representing the families Gomphidae, Libellulidae and Coenagrionidae were recorded for the state of Minas Gerais. Seventeen species were collected only during the rainy season and eight only during the dry season, while 18 species were found in both seasons. The rainy season had greater abundance, with four times as many individuals as the dry season. This study increases the number of records for Odonata in the Minas Gerais state, and reinforces the trend for greater predominance of this group during the rainy season in this biome.
\end{abstract}

Key-Words. Cerrado; Inventory; Damselfly; Dragonfly; Odonata.

\section{INTRODUCTION}

A total of 854 species of 146 genera of dragonflies (Odonata: Insecta) has been estimated to occur in Brazil (Pinto, 2018), which is considered the greatest number of species for any country in the Neotropical Region (von Ellenrieder, 2009). Despite the existence of numerous studies on odonates in Brazil, the diversity of some areas remains poorly-known. For example, there have only been a few sporadic odonate collections made in the Northeast Region of the country (De Marco \& Vianna, 2005). A total of 218 species of odonates was estimated for the state of Minas Gerais in Southeast Brazil in 1998 (Machado, 1998). Since then, however, 26 new odonate species have been described for state, increasing the total number of recorded species to at least 244 (Machado, 2000, 2002, 2005a, 2005b, 2006, 2007a, 2007b, 2010, 2015; Costa et al., 2000b; Tennessen, 2004; Garrison, 2006; Machado \& Bedê, 2006;
Pessacq \& Costa, 2007; Costa et al., 2009; Santos et al., 2010; Machado \& de Souza, 2014; Machado \& Bedê, 2015; Guillermo-Ferreira et al., 2016; Pinto \& Almeida, 2016; Ávila-Júnior et al., 2017).

Many studies of odonates in Minas Gerais have been carried out in the central and southern regions of the state (Souza et al., 2013; Almeida et al., 2013; Bedê et al., 2015), while other areas remain poorly sampled. For example, little is known about the odonate fauna of the Triângulo Mineiro Region in western Minas Gerais (e.g., Borges et al., 2019). This region should be considered a priority area for faunal surveys of odonates (De Marco \& Vianna, 2005) since rapid growth of agriculture has led to the loss of natural habitats (Lima, 1996).

Studies have shown that environmental alterations due to agricultural activities near watercourses can affect odonate biodiversity. This is because agriculture can have indirect negative effects on aquatic habitats, which are essential for 
the completion of the odonate life cycle, thus favoring a limited number of generalist species (Juen et al., 2014; Oliveira-Júnior et al., 2017). In addition, seasonality can have a temporal effect on diversity by altering aquatic invertebrate communities among seasons, especially since aquatic environments are particularly susceptible to seasonal changes (Bischof et al., 2013; Dijkstra et al., 2014).

There can be a lack of rainfall for a period of up to six months during the dry season of the Cerrado, which decreases the depth of water in rivers. The first rains after this period are incorporated by the hydromorphic soil of this biome, which is associated with underground basins, flooded areas and rivers (Fonseca, 2005). Therefore, seasonality can play an important role in odonate development, mainly due to changes in habitat and food availability (Corbet, 1999).

Considering the scarcity of information on the distribution of odonates in the Triângulo Mineiro Region, and the extension of agricultural landscapes therein (Lima, 1996; Silva, 2000), the main objective of the present study was to inventory the odonate fauna of a stretch of the Sucupira Reservoir on the Rio Uberabinha, Uberlândia, Minas Gerais, Brazil. This study also sought to: (1) evaluate the distribution of the sampled species in Brazil; and (2) document the species composition of the odonate fauna during the dry and rainy seasons.

\section{MATERIAL AND METHODS}

\section{Sampling area}

The study was carried out on 105.7 hectares of privately owned property on the banks of the Sucupira Reservoir of Rio Uberabinha (18 $59^{\prime} 16.8^{\prime \prime} \mathrm{S}$ and $\left.48^{\circ} 08^{\prime} 47.3^{\prime \prime} \mathrm{W}\right)$, located near ( $19 \mathrm{~km})$ the urban perimeter of the municipality of Uberlândia in Triângulo Mineiro, Minas Gerais (Fig. 1). Rio Uberabinha originates in the municipality of Uberaba, crosses the municipalities of Uberlândia and Tupaciguara, and then empties into Rio Araguari for a total length of $123 \mathrm{~km}$. The urban area of Uberlândia is supplied by two water catchment systems: Cachoeira do Sucupira (southeast zone of the city) and Bom Jardim (south zone of the city) (CONAMA, 2005, 2011). Different classes of water quality occur along the length of Rio Uberabinha, but CONAMA № 357 of 17 March 2005, as amended by Resolution № 430 of 13 May 2011, classifies the water as Class 3 - water that can be used for: supplying human consumption after conventional or advanced treatment; irrigating tree, cereal and forage crops; amateur fishing; secondary contact recreation; and watering cattle - which may explain the intense anthropic occupation of the area (CONAMA, 2005, 2011).

The Triângulo Mineiro Region is largely occupied by agricultural activities, which have intensified over the
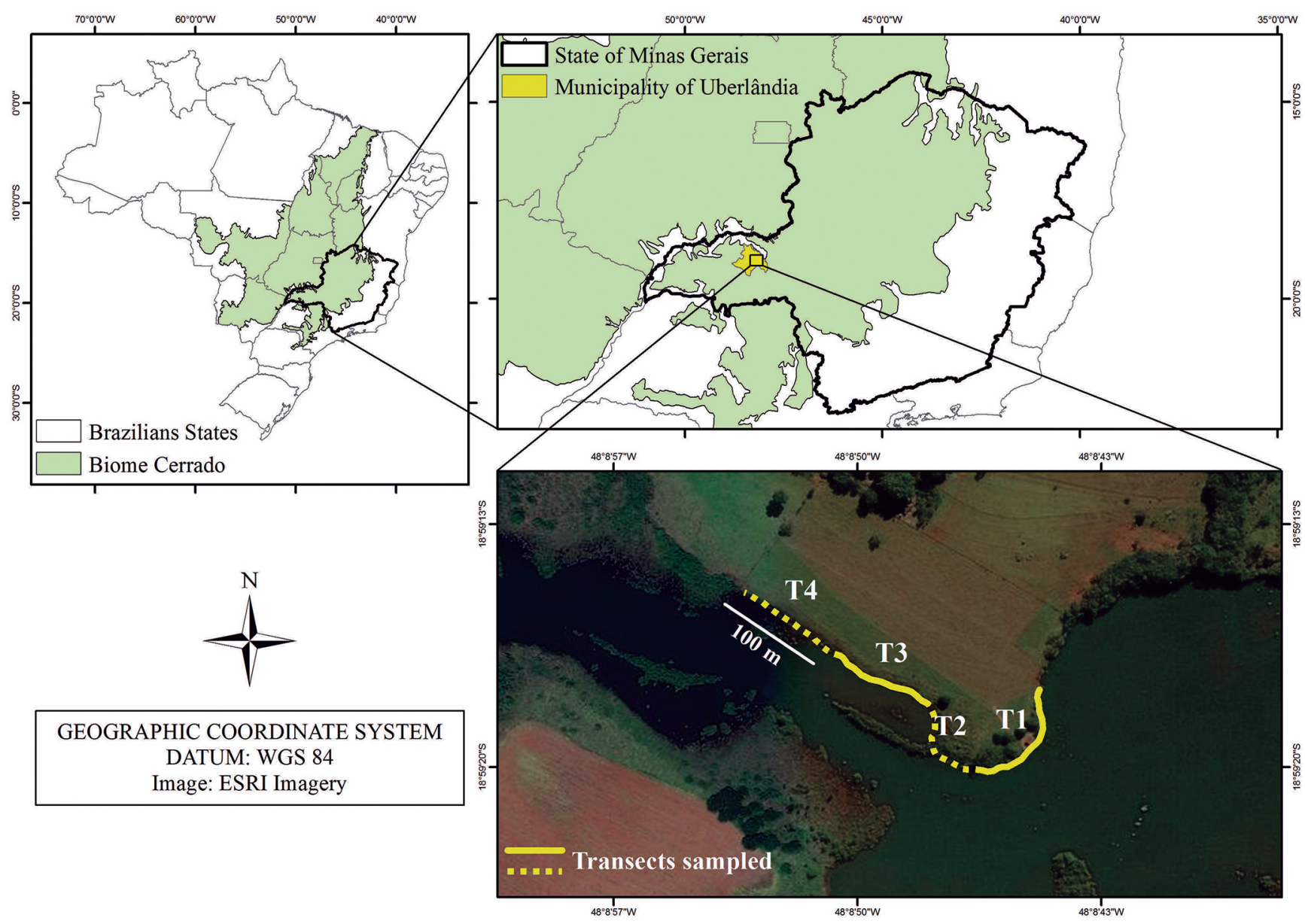

Figure 1. Map of the study area showing the collection sections/transects $(\mathrm{T} 1, \mathrm{~T} 2, \mathrm{~T} 3, \mathrm{~T} 4)$ and the watercourse of Rio Uberabinha, Uberlândia, Minas Gerais. 
last 50 years (Silva, 2000) resulting in a rapid reduction of natural areas (Lima, 1996). Most of the areas surrounding the study site possess a predominance of annual crops (corn, sunflower and soybean) and livestock activities, with few preserved areas. The section of Rio Uberabinha that passes through the study property, including the sampled area, is characterized as predominantly lentic, although the river below the reservoir is lotic. The analyzed sections possess a predominance of open areas with sparse shrubs and few trees. Like many areas of the Cerrado, the region experiences a seasonal climate, classified as Aw by the Köppen classification, with a hot and humid rainy season (October to March) and a cooler dry season (April to September). The mean annual temperature is $23^{\circ} \mathrm{C}$, while the mean annual precipitation is $1,350 \mathrm{~mm}$, with more than $80 \%$ of the rainfall being concentrated in the rainy season between November and March (Silva, 2000).

\section{Sampling and species identification}

Adult dragonflies were collected in four sections of the study property in August and September of 2017 (dry season) and in February and March of 2018 (rainy season). Sampling was performed during the daytime between 10:00 $\mathrm{h}$ and 15:00 $\mathrm{h}$, with a break from 12:00 $\mathrm{h}$ to 13:00 $\mathrm{h}$ - with a sampling effort of one hour per transect. The collection schedule was established based on studies that have shown the highest occurrence of odonates during the hotter periods of the day (Corbet, 1999; Hassall \& Thompson, 2008). Transects were established along four 100-meter stretches of the river around the reservoir, in places where it was possible for two collectors to operate (Fig. 1).

Adults were collected using entomological nets ("puçá" or long-handed hoop-net), with a 35-cm diameter hoop and a $60-\mathrm{cm}$ deep funnel. Samples were taken to the laboratory where they were kept in a freezer at $-15^{\circ} \mathrm{C}$ for three hours, after which they were immersed in acetone solution for a period of 8 to 16 hours (depending on specimen size) to dissolve fats and preserve color (O'Brien, 1997). The specimens were then dehydrated in an oven at $30^{\circ} \mathrm{C}$ for four hours. The specimens were ultimately identified to species with the aid of taxonomic keys (Lencioni, 2005, 2006, 2017; Garrison et al., 2006, 2010), and deposited in the Coleção Entomológica do Laboratório de Ecologia-Evolução da Biodiversidade, of the Universidade Federal de Uberlândia, Minas Gerais, Brazil. The collection license was granted by IBAMA through SISBIO under the number 28398-1.

\section{Statistical analysis}

The non-parametric Chao 1 estimator was used to estimate dragonfly richness for the study area and for each season separately. The estimator and rarefaction curves were obtained using EstimateS statistical program (Colwell, 2009), with 1000 replicates.

\section{RESULTS}

A total of 860 individuals of 43 species distributed among 26 genera and six families were collected (Table 1). Some sampled species of the families Gomphidae, Libellulidae, Coenagrionidae and Calopterygidae are illustrated in Fig. 2. The rarefaction curve based on the sampling data of both seasons displays the sampling effectiveness for the study (Fig. 3). The richness of species collected corresponds to $71.3 \%$ of the mean estimated richness for the area by Chao 1 (59.9 \pm 11.9$)$ (Fig. 3). The richness of species collected during the dry season (26) corresponds to $80.6 \%$ of the mean estimated richness $(31.0 \pm 6.4)$, while that collected during the rainy season (35), corresponds to $76.1 \%$ of the mean estimated richness (64.24 \pm 12.24) (Fig. 4A).

The number of species collected in the rainy season was 1.35 times that collected in the dry season, and with, on average, four times more individuals. Two rarefaction curves showing the effectiveness of the sampling effort in each season can be seen in Fig. 4A. The Venn diagram shows that $41.86 \%$ of the species were common to both seasons. A total of 35 species were collected during the rainy season, 17 of which were only collected then ( $40 \%$ of all species found), while a total of 25 species were collected during the dry season, eight of which were collected only then ( $19 \%$ of all species found) (Fig. 4B).

\section{DISCUSSION}

The number of studies involving odonates in Brazil has been increasing over the last several years, with many of them involving ecology and taxonomy (Miguel et al., 2017). Ângelo Machado has made numerous contributions regarding odonates in many areas of Minas Gerais, including new findings and taxonomic descriptions of several species (see References for a list of new odonate species described by Machado from Minas Gerais since 1998). Other lists for different regions and biomes of the state have since been produced (Souza et al., 2013; Almeida et al., 2013; Bedê et al., 2015; Souza et al., 2017). Nonetheless, information regarding odonates is still lacking for Triângulo Mineiro, a region in the Cerrado biome, which is a world biodiversity hotspot (Myers et al., 2000). This lack of information is unsettling given the extensive occupation by livestock and farming activities (Silva, 2000). The present study contributed six new odonate records for the state, with species belonging to the families Coenagrionidae, Gomphidae and Libellulidae. These results demonstrate the need for more studies to better understand the distribution of these insects in this region.

Reported values for odonate species richness in the Cerrado biome range from 26 to 85 (Ferreira-Peruquetti \& Fonseca-Gessner, 2003; Almeida et al., 2013; Calvão et al., 2014; Dutra \& De Marco, 2015; Vilela et al., 2016; Souza et al., 2017; Klein et al., 2018; Borges et al., 2019). Considering that studies reporting higher species richness in the Cerrado were done at larger sites with larger 

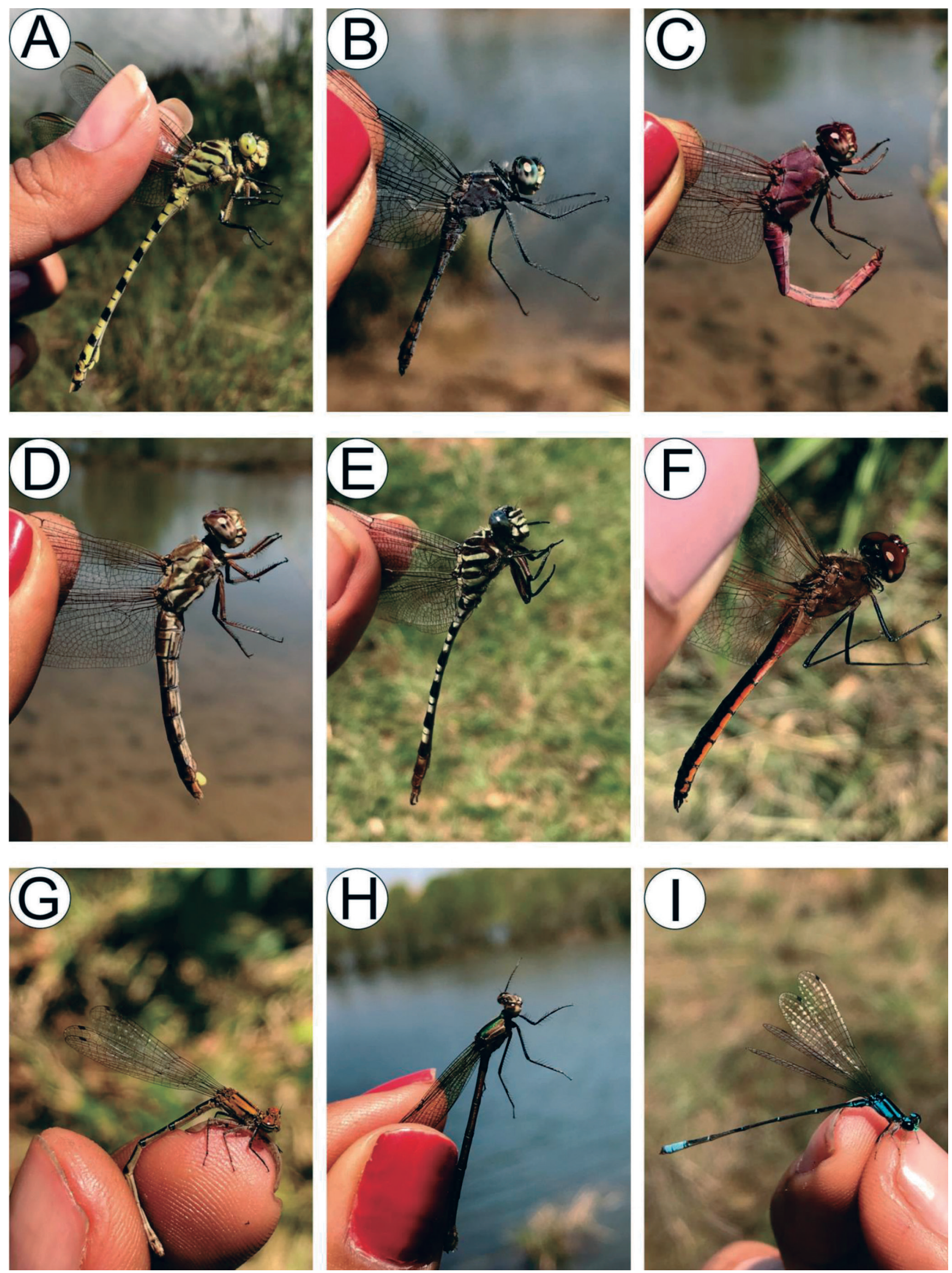

Figure 2. Odonate species sampled in the study area. (A) Aphylla distinguenda - Male (Gomphidae), (B) Oligoclada stenoptera - Male (Libellulidae), (C) Orthemis discolor - Male (Libellulidae), (D) Orthemis aequilibris - Female (Libellulidae), (E) Phyllocycla gladiata - Male (Gomphidae), (F) Idiataphe longipes - Young male (Libellulidae), (G) Tigriagrion aurantinigrum - Female (Coenagrionidae), (H) Hetaerina rosea - Female (Calopterygidae) and (I) Acanthagrion gracile - Male (Coenagrionidae). 


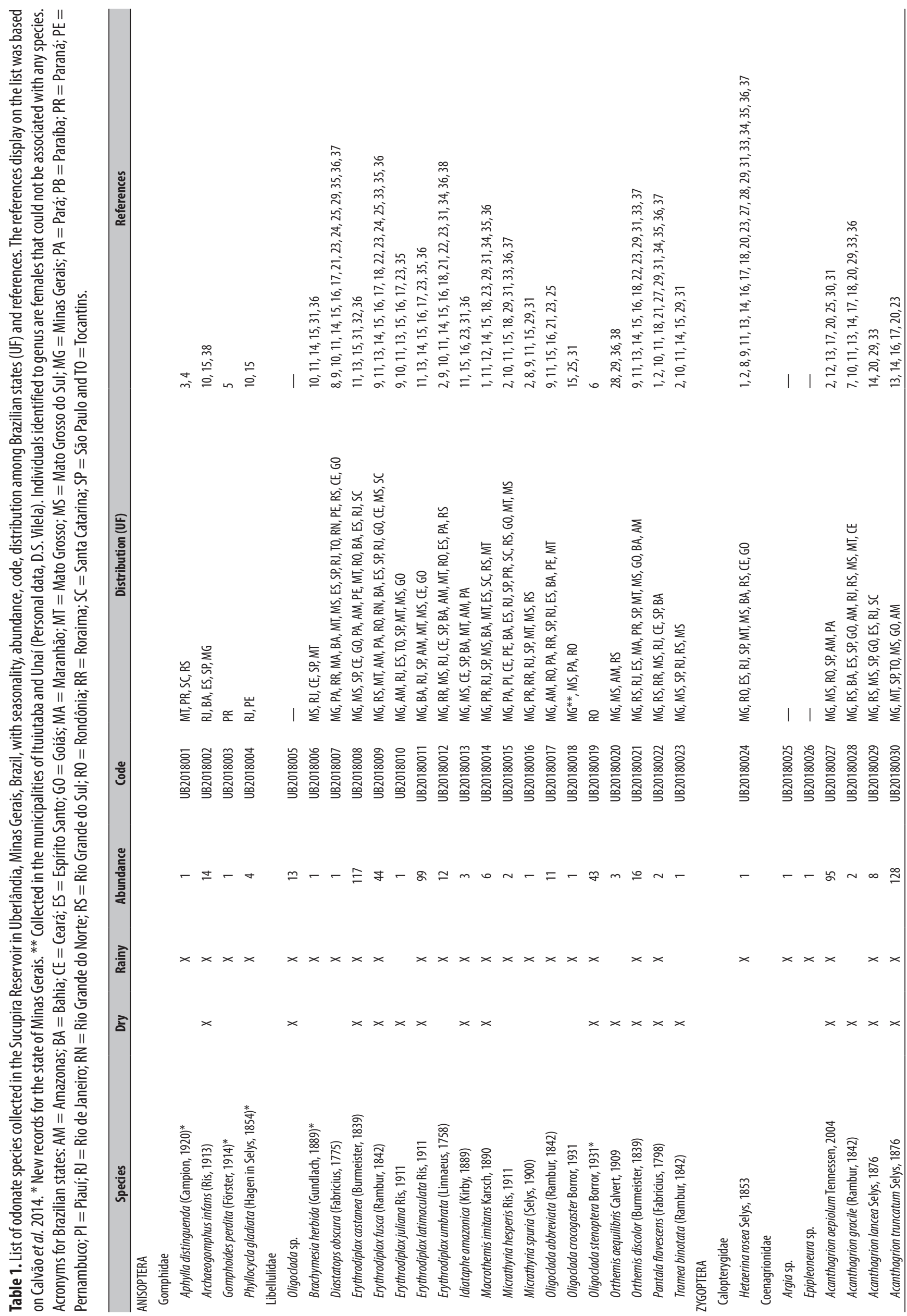




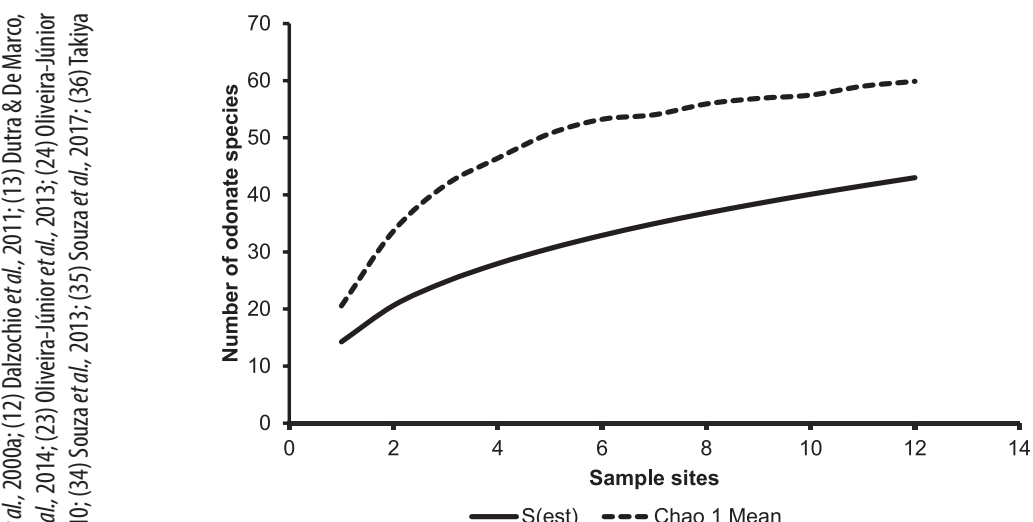

Figure 3. Odonate species rarefaction curve and the number of species estimated by the Chao 1 estimator during the rainy and dry seasons in the study area in Uberlândia, Minas Gerais.

proportions of preserved areas, the richness found by the present study (43 species) can be considered average, even given its relatively small and highly-degraded area. This result may be due, in part, to the large sampling effort of the present study, which resulted in sampling $72.9 \%$ of the species richness estimated by the Chao 1 estimator (Chao, 1984, 1987).

A study performed in Reserva Ecológica do Clube Caça e Pesca Itororó de Uberlândia, in the municipality of Uberlândia, which encompasses 640 ha (Vilela et al., 2016), encountered 31 species along a 500 meter section of the stream and pond of the reserve, which is a relatively low number compared to other such studies in the Cerrado biome. Nonetheless, a new species of the family Libellulidae was found at this site: Erythrodiplax ana Guillermo-Ferreira \& Vilela, 2016 (Guillermo-Ferreira et al., 2016). A new species was also found by a recent study at Fazenda Nova Monte Carmelo in the Triângulo Mineiro Region; a species of the genus Tigriagrion (Coenagrionidae), which is currently being described (Borges et al., 2019). These data suggest that this relatively unexplored area of the Cerrado is likely to possess yet additional new odonate species.

The present study recorded species that are rarely sampled in inventories, such as Cyanallagma angelae Lencioni, 2001; Cyanallagma nigrinuchale Selys, 1876; Homeoura lindneri Ris, 1928; Lestes minutus Selys, 1862; Nehalennia minuta Kirby, 1890; and Phyllocycla gladiata Selys, 1854, suggesting that the surroundings of Rio Uberabinha, as well as other areas of the Triângulo Mineiro Region, still have the potential for the existence of species that have limited distributions, despite it being degraded (see Table 1). Furthermore, some areas are important for conserving odonate diversity, and thus should be prioritized for the preservation of these insects (Borges et al., 2019).

The species of the family Gomphidae are known to secretive, many of which are also evasive, thus making them difficult to collect by the traditional method of entomological nets (Almeida et al., 2013). This may explain why few individuals of this family are sampled by inventories, and why three of four species of Gomphidae collected in the present study were new records for Minas 

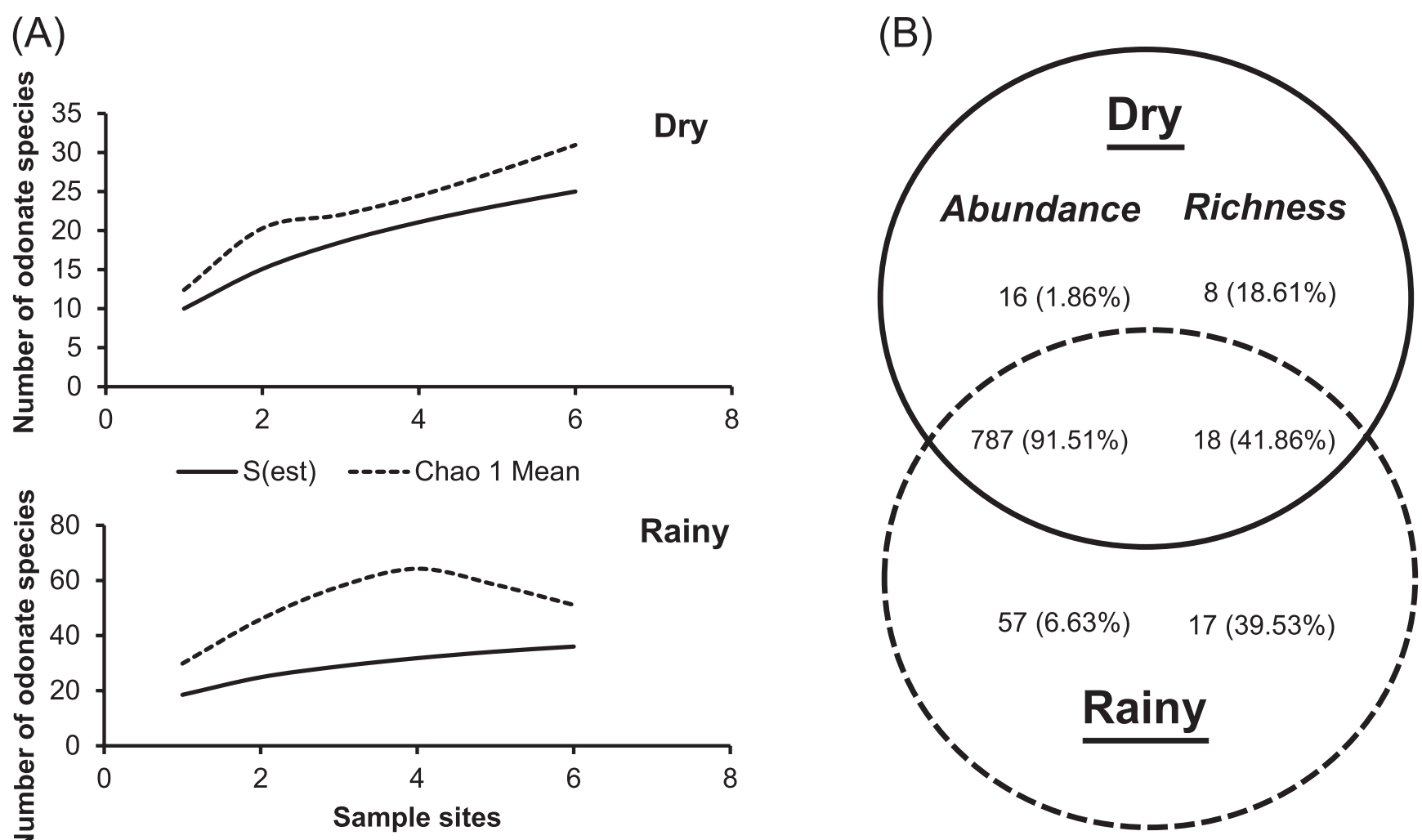

- S(est) -.-.- Chao 1 Mean

Figure 4. Comparison of species richness and abundance between rainy and dry seasons in the Sucupira Reservoir: (A) Odonate species rarefaction curves in each season. (B) Venn diagram showing the distribution of species between the seasons including the percentage of species common to both seasons.

Gerais. Some faunal studies in the Cerrado and other biomes have found species of Gomphidae to account for only $5 \%$ of the total odonate species richness sampled, while species belonging to Libellulidae generally dominated, which is a family known to have species with abundant and common populations (e.g., Machado et al., 1991; Ferreira-Peruquetti \& Fonseca-Gessner, 2003).

Nonetheless, the present study still found species of Libellulidae that had not been observed in previous inventories in Minas Gerais. One of these species was Oligoclada stenoptera, which is known from Ecuador where the genus Oligoclada is well represented (Rehn, 2003). In Brazil, as far we know, this species has only been documented in the state of Rondônia in the North Region of Brazil (Borror, 1931). Additionally, the species Brachymesia herbida, although widely distributed throughout Brazil, had not previously been reported in Minas Gerais (Table 1).

Aquatic invertebrate communities can vary among seasons since aquatic environments are particularly susceptible to seasonal changes (Bischof et al., 2013; Dijkstra et al., 2014). Changes in hydrology can influence odonate community composition due to changes in habitat and food availability (Corbet, 1999). The present study found species richness to be higher during the rainy season, as was similarly reported by Vilela et al. (2016), with 68\% of the species sampled being exclusive to the rainy season and only $6.5 \%$ exclusive to the dry season. Likewise, Ferreira-Peruquetti \& Fonseca-Gessner (2003) reported $42 \%$ of species sampled to be exclusive to the rainy season and only $14 \%$ exclusive to the dry season. These studies suggest that many odonates appear only during the rainy season, which is likely due to the availability of prey and resources for adult and larvae development.

\section{CONCLUSION}

The present study contributes relevant information about the richness, composition and distribution of species of odonates in the Triângulo Mineiro Region of Minas Gerais in particular, and the Cerrado biome in general. In addition, several rare species were recorded, as well as new records for the state. These new records are of great importance because they significantly increase knowledge regarding the distributions of these species, which are now known to include an area with a high level of anthropization. Therefore, given the size of the Triângulo Mineiro Region and the existence of extensive areas of agriculture and livestock, as well as the scarcity of studies on the diversity of odonates therein. Additional studies of odonates are needed for the region (De Marco \& Vianna, 2005) to facilitate the development of conservation plans for this diverse group of insects.

\section{ACKNOWLEDGEMENTS}

We would like to thank the staff of the Laboratório de Ecologia, Evolução \& Biodiversidade for field and 
laboratorial support. This study received financial support from CNPq (National Counsel of Technological and Scientific Development, 312752/2018-0, 140732/2016-0, 145872/2018-1 and 140158/2018-9), Capes (Coordination for the Improvement of Higher Education Personnel), and Fapemig (Foundation of Support Research of the State of Minas Gerais), and Duratex S.A.

Authors' Contributions. Substantial contribution in the concept and design of the study (MSB, LRB \& JCS). Contribution to data collection (MSB, LRB \& HV). Contribution to data analysis and interpretation (MSB, LRB, DSV, HV \& JCS). Contribution to manuscript preparation (MSB, LRB, HV \& JCS). Contribution to critical revision, adding intellectual content (MSB, LRB, DSV, HV \& JCS).

\section{REFERENCES}

Almeida, M.V.O.; Pinto, A.P.; Carvalho, A.L. \& Takiya, D.M. 2013. When rare is just a matter of sampling: Unexpected dominance of clubtail dragonflies (Odonata, Gomphidae) throught differente collecting methods at Parque Nacional da Serra do Cipó, Minas Gerais State, Brazil. Revista Brasileira de Entomologia, 57(4): 417-423.

Ávila-Júnior, W.F.; Lencioni, F.A.A. \& Carneiro, M.A.A. 2017. Heteragrion cauei sp. nov., a new damselfly from Minas Gerais, Brazil (Odonata: Heteragrionidae). Odonatologica, 46(3/4): 275-286.

Bedê, L.C.; Machado, A.B.M.; Piper, W. \& Souza, M.M. 2015. Odonata of the Serra de São José - Brazil's first Wildlife Reserve aimed at the conservation of dragonflies. Notulae Odonatologicae, 8(5): 117-155.

Belle, J. 1992. A revision of the South American species of Aphylla selys, 1854 (Odonata: Gomphidae). Zoologische Mededelingen, 66(12): 239-264.

Belle, J. 1994. Four new species of Aphylla from Brazil (Odonata: Gomphidae). Entomologische Berichten, 54(7): 138-144.

Belle, J. 1995. On the female sex of some elusive South-American Gomphidae with the descriptions of three new genera and four new species (Odonata). Zoologische Mededelingen, 69: 19-36.

Bischof, M.M.; Hanson, M.A.; Fulton, M.R.; Kolka, R.K.; Sebestyen, S.D. \& Butler, M.G. 2013. Invertebrate Community Patterns in Seasonal Ponds in Minnesota, USA: Response to Hydrologic and Environmental Variability. Wetlands, 33: 245-256.

Borges, L.R.; Barbosa, M.S.; Carneiro, M.A.A.; Vilela, D.S.; Santos, J.C. 2019. Dragonflies and damselflies (Insecta: Odonata) from a Cerrado area at Triângulo Mineiro, Minas Gerais, Brazil. Biota Neotropica, 19(1): e20180609.

Borror, D.J. 1931. The Genus Oligoclada (Odonata). Miscellaneous Publications of the Museum of Zoology, University of Michigan, 22: 1-42.

Brasil, L.S.; Batista, J.D.; Giehl, N.F.S.; Valadão, M.B.X.; Santos, J.0.\& Dias-Silva, K. 2014. Environmental integrity and damselfly species composition in Amazonian streams at the "arc of deforestation" region, Mato Grosso, Brazil. Acta Limnologica Brasiliensia, 26(3): 278-287.

Calvão, L.B.; De Marco, P. \& Batista, J.D. 2014. Odonata (Insecta) from Nova Xavantina, Mato Grosso, Central Brazil: Information on species distribution and new records. Check List, 10(2): 299-307.

Carvalho, A.L. \& Nessimian, J.L. 1998. Odonata do Estado do Rio de Janeiro, Brasil: hábitats e hábitos das larvas. In: Nessimian, J.L. \& Carvalho, A.L. (Eds.). Ecologia de Insetos Aquáticos. Rio de Janeiro, UFRJ, PPGE. p. 03-28. (Séries Oecologia Brasiliensis, v. 5)

Carvalho, F.G.; Pinto, N.S.; Oliveira-Júnior, J.M.B. \& Juen, L. 2013. Effects of marginal vegetation removal on Odonata communities. Acta Limnologica Brasiliensia, 25(1): 10-18.
Chao, A. 1984. Nonparametric estimation of the number of classes in a population. Scandinavian Journal of Statistics, 11(4): 265-270.

Chao, A. 1987. Estimating the population size for capture-recapture Data with unequal catchability. Biometrics, 43(4): 783-791.

Colwell, R.K. 2009. EstimateS: statistical estimates of species richness and shared species from samples, version 6.0 b1: user's guide and application. Available at: http://viceroy.eeb.uconn.edu/estimates. Access in: 04/23/2018.

Conselho Nacional do Meio Ambiente (CONAMA). 2005. Resolução CONAMA 357, de 17 de março de 2005. Available at: http://mma.gov.br/port/ conama/res/res05/res35705.pdf. Access in: 01/10/2018.

Conselho Nacional do Meio Ambiente (CONAMA). 2011. Resolução CONAMA 430, de 13 de maio de 2011. Available at: http://mma.gov.br/port/ conama/legiabre.cfm?codlegi=646. Access in: 01/15/2018.

Corbet, P.S. 1999. Dragonflies: behaviour and ecology of Odonata. Ithaca, Cornell University Press. 829p.

Costa, J.M.; Machado, A.B.M.; Lencioni, F.A.A. \& Santos, T.C. 2000a. Diversidade e distribuição dos Odonata (Insecta) no Estado de São Paulo, Brasil: Parte I - Lista das espécies e registros bibliográficos. Publicações Avulsas do Museu Nacional, 80: 1-27.

Costa, J.M.; De Souza, L.I. \& Santos, T.C. 2000b. Two new species of Oxyagrion Selys, 1876, with a description of five new larvae (Zygoptera: (oenagrionidae). Odonatologica, 29(1): 1-15.

Costa, J.M.; Santos, T.C. \& de Souza, L.0.I. 2009. Cyanallagma corbeti sp. nov., from Brazil (0donata: Coenagrionidae). International Journal of Odonatology, 12(2): 323-329.

Dalzochio, M.S.; Souza, L.0.I.; Uchoa, M.A. \& Costa, J.M. 2011. First records of Odonata (Insecta) from the Bodoquena Mountains, Mato Grosso do Sul, Brazil. EntomoBrasilis, 4(3): 135-138.

De Marco, P. \& Vianna, D.M. 2005. Distribuição do esforço de coleta de Odonata no Brasil - subsídios para escolha de áreas prioritárias para levantamentos faunísticos. Lundiana, 6: 13-26.

Dijkstra, K.D.B.; Monaghan, M.T. \& Pauls, S.U. 2014. Freshwater biodiversity and aquatic insect diversification. Annual Review of Entomology, 59: 143-163.

Dutra, S. \& De Marco, P. 2015. Bionomic differences in odonates and their influence on the efficiency of indicator species of environmental quality. Ecological Indicators, 49: 132-142.

Ferreira-Peruquetti, P. \& Fonseca-Gessner, A.A. 2003. Comunidade de Odonata (Insecta) em áreas naturais de Cerrado e monocultura no nordeste do Estado de São Paulo, Brasil: relação entre o uso do solo e riqueza faunística. Revista Brasileira de Zoologia, 20(2): 219-224.

Fonseca, C.P. 2005. Caracterização dos Ecossistemas Aquáticos do Cerrado. In: Scariot, A.; Sousa-Silva, J.C. \& Felfili, J.M. (Eds.). Cerrado: Ecologia, Biodiversidade e Conservação. Brasília, Ministério do Meio Ambiente. p. 25-44.

Garrison, R.W. 2006. A synopsis of the genera Mnesarete Cowley, Bryoplathanon gen. nov., and Ormenoplebia gen. nov. (Odonata: Calopterygidae). Contributions in Science, Natural History Museum of Los Angeles County. 87p.

Garrison, R.W.; von Ellenrieder, N. \& Louton, J.A. 2010. Damselfly genera of the New World. An illustrated and annotated key to the Zygoptera. Baltimore, The Johns Hopkins University Press. 490p.

Garrison, R.W.; von Ellenrieder, N. \& Louton, J.A. 2006. Dragonfly genera of the new world: an illustrated and annotated key to the Anisoptera. Baltimore, The John Hopkins University Press. 368p.

Guillermo-Ferreira, R.; Vilela, D.S.; Del-Claro, K. \& Bispo, P.C. 2016. Erythrodiplax ana sp. nov. (Odonata: Libellulidae) from Brazilian palm swamps. Zootaxa, 4158(2): 292-300.

Hassall, C. \& Thompson, D.J. 2008. The effects of environmental warming on Odonata: a review. International Journal of Odonatology, 11: 131-153. 
Heckman, C.W. 2006. Encyclopedia of South American Aquatic Insects: Odonata - Anisoptera. Dordrecht, Springer. 726p.

Juen, L.; Oliveira-Júnior, J.M.B.; Shimano, Y.; Mendes, T.P. \& Cabette, H.S.R. 2014. Composição e riqueza de Odonata (Insecta) em riachos com diferentes níveis de conservação em um ecótone Cerrado-Floresta Amazônica. Acta Amazonica, 44(2): 175-184.

Klein, C.E.; Pinto, N.S.; Spigoloni, Z.A.V.; Bergamini, F.M.; De Melo, F.R.; De Marco, P. \& Juen, L. 2018. The influence of small hydroelectric power plants on the richness and composition of Odonata species in the Brazilian Savanna. International Journal of Odonatology, 21(1): 33-44.

Koroiva, R.; Rodrigues, M.E.; Valente-Neto, F. \& Roque, F.0. 2017. Odonates from Bodoquena Plateau: checklist and information about endangered species. Biota Neotropica, 17(3): e20160310.

Lencioni, F.A.A. 2005. The Damselflies of Brazil:An Illustrated Identification Guide 1 - The Non-Coenagrionidae families. São Paulo, All Print Editora. 332p.

Lencioni, F.A.A. 2006. Damselflies of Brazil: An Illustrated Identification Guide 2 - Coenagrionidae families. São Paulo, All Print. 419p.

Lencioni, F.A.A. 2017. Damselflies of Brazil: An Illustrated Identification Guide Southeast region. Jacareí, SP, Ed. do Autor. 559p.

Lima, S.C. 1996. As veredas do Ribeirão Panga no Triângulo Mineiro e a evolução da paisagem. (Doctoral Thesis in Physical Geography). São Paulo, Universidade de São Paulo (USP). 274p.

Machado, A.B.M. 1998. Livro Vermelho das espécies ameaçadas de extinção da fauna de Minas Gerais. Belo Horizonte, Fundação Biodiversitas. 605p.

Machado, A.B.M. 2000. Studies on Neotropical Protoneuridae. 10. Forcepsioneura lucia sp. n., from the Parque Estadual Rola Moça, Minas Gerais, Brazil (Odonata, Zygoptera). Boletim do Museu de Biologia Mello Leitão, 11.

Machado, A.B.M. 2002. Description of Lauromacromia flaviae spec. nov., with notes on the holotype of L. luismoojeni (Santos) (Anisoptera: Corduliidae). Odonatologica, 31(3): 313-318.

Machado, A.B.M. 2005a. Lauromacromia bedei sp. nov., from the State of Minas Gerais, Brazil (Odonata, Corduliidae). Revista Brasileira de Entomologia, 49(4): 453-456.

Machado, A.B.M. 2005b. Neocordulia matutuensis spec. nov., from Brazil (Anisoptera: Corduliidae). Odonatologica, 34(3): 299-302.

Machado, A.B.M. 2006. Three new species of Heteragrion Selys, from Brazil with redescription of the holotype of $H$. dorsale Selys (Odonata, Megapodagrionidae). Revista Brasileira de Zoologia, 23(4): 1062-1070.

Machado, A.B.M. 2007a. Leptagrion afonsoi sp. n., from the state of Minas Gerais, Brazil (Odonata: Coenagrionidae). Lundiana, 7: 125-126.

Machado, A.B.M. 2007b. Studies on Neotropical Protoneuridae. 20. Neoneura kiautai spec. nov., from southeastern Brazil (Zygoptera, Protoneuridae). In: Tyagi, B.K. (Ed.). Odonata: biology of dragonflies. Buckinghamshire, Pemberley Publs. p. 25-32.

Machado, A.B.M. 2010. Oxyagrion mirnae spec. nov., from Brazil (Zygoptera: Coenagrionidae). Odonatologica, 39(4): 353-356.

Machado, A.B.M. 2015. Heteragrion thais sp. nov., from the Atlantic Forest of Brazil (Odonata: Heteragrionidae). Odonatologica, 44(3): 391-396.

Machado, A.B.M. \& Bedê, L.C. 2006. Heteragrion tiradentense spec. nov., from the state of Minas Gerais, Brazil (Zygoptera: Megapodagrionidae). Odonatologica, 35(1): 47-54.

Machado, A.B.M. \& Bedê, L.C. 2015. Two new genera and nine new species of damselflies from a localized area in Minas Gerais, Brazil (Odonata: Zygoptera). International Journal of Odonatology, 18: 269-296.

Machado, A.B.M. \& de Souza, M.M. 2014. A remarkable new species of Heteragrion from Brazil (0donata: Megapodagrionidae). International Journal of Odonatology, 17(2-3): 95-99.

Machado, A.B.M.; Mesquita, H.G. \& Machado, P.A.R. 1991. Contribuição ao conhecimento dos odonatos da Estação Ecológica de Maracá. Acta Amazonica, 21: 159-173.
Miguel, T.B.; Calvão, L.B.; Vital, M.V.C. \& Juen, L. 2017. A scientometric study of the order Odonata with special attention to Brazil. International Journal of Odonatology, 20(1): 27-42. D0l

Monteiro-Júnior, C.S.; Juen, L. \& Hamada, N. 2014. Effects of urbanization on stream habitats and associated adult dragonfly and damselfly communities in central Brazilian Amazonia. Landscape and Urban Planing, 127: 28-40.

Myers, N.; Mittermeier, R.A.; Mittermeier, C.G.; Fonseca, G.A.B. \& Kent, J. 2000. Biodiversity hotspots for conservation priorities. Nature (403): 853-858.

0'Brien, M. 1997. Michigan Odonata Survey's Collector Manual version 1.0. University of Michigan. Available at: http://michodonata.org/ moshandbk.pdf. Access in: 02/12/2019. 36p.

Oliveira-Júnior, J.M.B.; Cabette, H.S.R.; Silva-Pinto, N. \& Juen, L. 2013. As variações na comunidade de Odonata (Insecta) em córregos podem ser preditas pelo Paradoxo do Plâncton? Explicando a Riqueza de Espécies Pela Variabilidade Ambiental. EntomoBrasilis, 6(1): 1-8.

Oliveira-Júnior, J.M.B.; De Marco, P; Dias-Silva, K.; Leitão, R.P.; Leal, C.G.; Pompeu, P.S.; Gardner, T.A.; Hughes, R.M. \& Juen, L. 2017. Effects of human disturbance and riparian conditions on Odonata (Insecta) assemblages in eastern Amazon basin streams. Limnologica, 66: 31-39.

Oliveira-Júnior, J.M.B.; Shimano, Y.; Gardner, T.A.; Hughes, R.M.; De Marco, P. \& Juen, L. 2015. Neotropical dragonflies (Insecta: Odonata) as indicators of ecological condition of small streams in the eastern Amazon. Austral Ecology, 40(6): 733-744.

Pessacq, P. \& Costa, J.M. 2007. Three new species of Peristicta Hagen in Selys (Odonata: Zygoptera: Protoneuridae) from Brazil. Neotropical Entomology, 36(1): 46-52.

Pinto, A.P. 2018. Odonata In: Catálogo taxonômico da fauna do Brasil. Available at: http://fauna.jbri.gov.br/fauna/faunadobrasil/171. Access in: 05/29/2018.

Pinto, A.P. \& Almeida, M.V.0. 2016. A taxonomic synopsis of South American Cyanogomphini Carle with description of (yanogomphus angelomachadoi sp. nov., from the Cerrado of Brazil (0donata: Gomphidae). Zootaxa, 4078(1): 38-69.

Pires, M.M.; Kotzian, C.B.; Spies, M.R. \& Neri, D.B. 2013. Diversity of Odonata (Insecta) larvae in streams and farm ponds of a montane region in southern Brazil. Biota Neotropica, 13(3): 259-267.

Rehn, A.C. 2003. Oligoclada teretidentis spec. nov., from eastern ecuador (Anisoptera: Libellulidae). Odonatologica, 32(2): 171-175.

Renner, S.; Périco, E. \& Sahlén, G. 2016. List of Odonates from the Floresta Nacional de São Francisco de Paula (FLONA - SFP), with two new distribution records for Rio Grande do Sul, Brazil. Biota Neotropica, 16(3): e20150132.

Renner, S.; Périco, E.; Ely, G.J. \& Sahlén, G. 2017. Preliminary dragonfly (Odonata) species list from the Pampa biome in Rio Grande do Sul, Brazil, with ecological notes for 19 new records for the State. Biota Neotropica, 17(4): e20170374.

Renner, S.; Périco, E.; Sahlén, G.; Santos, D.M. \& Consatti, G. 2015. Dragonflies (Odonata) from the Taquari River valley region, Rio Grande do Sul, Brazil. Check List, 11(5): 1740-1746.

Rodrigues, M.E. \& Roque, F.0. 2017. Checklist de Odonata do Estado de Mato Grosso do Sul, Brasil. Iheringia Série Zoologia, 107: 107-111.

Rodrigues, M.E.; Roque, F.0.; Quintero, J.M.O.; Pena, J.C.C.; Souza, D.C. \& De Marco, P. 2016. Nonlinear responses in damselfly community along a gradient of habitat loss in a savanna landscape. Biological Conservation, 194: $113-120$

Santos, N.D. 1966. Odonatas da região de Poços de Caldas, Minas Gerais. Atas da Sociedade de Biologia do Rio de Janeiro, 10: 65-69.

Santos, T.C.; Costa, J.M. \& Carriço, C. 2010. A new species of Neocordulia Selys, 1882 (0donata: Corduliidae) from Minas Gerais State, Brazil. Biota Neotropica, 10(2): 89-91. 
Silva, D.P.; De Marco, P. \& Resende, D.C. 2010. Adult odonate abundance and community assemblage measures as indicators of stream ecological integrity: A case of study. Ecological Indicators, 10: 744-752.

Silva, L.L. 2000. 0 papel do Estado no processo de ocupação das áreas de Cerrado entre as décadas de 60 e 80. Caminhos de Geografia, 1(2): 24-36.

Souza, M.M.; Pires, E.P.; Brunismann, Â.G.; Milani, L.R. \& Pinto, Â.P. 2017. Dragonflies and damselflies (Odonata) from the wetland of the Rio Pandeiros, northern region of Minas Gerais State, Brazil, with a description of the male of Archaeogomphus vanbrinki Machado (Anisoptera: Gomphidae). International Journal of Odonatology, 20(1): 13-26.

Souza, M.M.; Souza, B.; Pereira, M.C.S.A. \& Machado, A.B.M. 2013. List of Odonates from Mata do Baú, Barroso, Minas Gerais, Brazil. Check List, 9(6): 1367-1370.
Takiya, D.; Santos, A.; Pinto, Â.; Henriques-Oliveira, A.; Carvalho, A.; Sampaio, B.; Clarkson, B.; Moreira, F.; Avelino-Capistrano, F.; Gonçalves, I.; Cordeiro, I.; Câmara, J.; Barbosa, J.; De Souza, W. \& Rafael, J. 2016. Aquatic Insects from the Caatinga: checklists and diversity assessments of Ubajara (Ceará State) and Sete Cidades (Piauí State) National Parks, Northeastern Brazil. Biodiversity Data Journal, 4: e8354.

Tennessen, K.J. 2004. Acanthagrion aepiolum sp. nov., from South America (Odonata: Coenagrionidae). International Journal of Odonatology, 7: 79-86.

Vilela, D.S.; Guillermo-Ferreira, R. \& Del-Claro, K. 2016. The odonata community of a Brazilian vereda: Seasonal patterns, species diversity and rarity in a palm swamp environment. Bioscience Journal, 32(2): 486-495.

von Ellenrieder, N. 2009. Databasing dragonflies: state of knowledge in the Neotropical region. Agrion, 13(2): 58-72. 